\title{
Conserving the Seychelles Warbler Acrocephalus sechellensis by translocation: a transfer from Cousin Island to Aride Island
}

\author{
JAN KOMDEUR, IAN D. BULLOCK and MICHAEL R. W. RANDS
}

\begin{abstract}
Summary
The Seychelles Warbler was once a highly threatened single-island endemic species with a population of 26 individuals confined to Cousin Island in the inner Seychelles. Following long-term management of Cousin, the population steadily recovered to around $300-$ 360 birds. Given the vulnerability of one small island in the Indian Ocean, the possibility of establishing the species on additional islands had been proposed as a priority conservation measure. This paper describes the successful translocation of 29 Seychelles Warblers from Cousin to Aride, summarizes the ecological studies carried out prior to, during and after the translocation and documents the subsequent establishment of the new population. It is considered that the Seychelles Warbler will soon no longer be a globally threatened species.
\end{abstract}

Le Petit Merle des lles fut jadis une espèce hautement menacée, confinée à une seule île avec une population de 26 individus sur l'île Cousin de l'archipel intérieur des Seychelles seulement. En 1968 cette île fut acheté pour le Conseil International pour la Protection des Oiseaux (CIPO/ICBP) afin d'assurer une gestion à long terme, de façon que la population augmenta jusqu'à 300-360 individus. A ce stade la capacité de l'île fut apparemment atteint. Etant donné la vulnérabilité d'une seule petite île dans l'Océan Indien, la possibilité d'établir l'espèce sur d'autres îles fut proposé comme mesure prioritaire de conservation. Notre contribution décrit le transfer réussi de 29 Petits Merles des lles de Cousin à Aride, récapitule les études écologiques entrepris avant, pendant et après le transfer et documente l'établissement suivant de la nouvelle population. Ainsi on considère le Petit Merle des lles ne plus faire partie des espèces menacées globalement bientôt.

\section{Introduction}

The oceanic islands of the western Indian Ocean support 26 globally threatened bird taxa that are listed in the ICBP/IUCN Bird Red Data Book and include some of the smallest and most threatened bird populations in the world (see Collar and Stuart 1985). In the central group of the Seychelles eight taxa are threatened. One of these is the Seychelles Warbler Acrocephalus sechellensis (Oustalet 1878), which at one time was reduced to a population of 26 individuals entirely confined to Cousin Island (29 ha) (Crook 1960). In September 198829 warblers were transferred to Aride Island (68 ha), in order to give the species security of a second breeding population, lest some ecological disaster should befall the parent population. Data included in this study were based on the entire world 
population of Seychelles Warblers, which is a group-territorial species. Since January 1986 all 115-123 groups of the warblers (300-36o birds) have been studied on Cousin Island by one of us (J.K.), and from September 1988 to March 1989 an additional $13-16$ groups (29-45 birds) on Aride Island (by I.D.B.).

\section{Past and present distribution of the Seychelles Warbler}

The Seychelles Warbler is known only from the Seychelles Islands, where in 1870 it was recorded on Marianne and Cousine (Oustalet 1878, Figure 1). Between 1910 and 1920 both islands were planted with coconuts (Cocos nucifera); this caused the removal of all original indigenous vegetation, which resulted in the disappearance of the species from both. Odd records have been reported from Mahé and Felicité and there is some confusion as to whether the original Cousine record may have been in error for Cousin (see Collar and Stuart 1985). The species was certainly present on Cousin in 1938 but was by then considered rare (see Collar and Stuart 1985). No other self-sustaining population existed until September 1988.

In 1959 a survey of Cousin revealed a population of 26 birds only (Crook 1960). Since the species was believed to be on the verge of extinction, Cousin was purchased for the International Council for Bird Preservation in 1968, which has since managed the island as a nature reserve. Management has been directed towards increasing suitable habitat for the warbler. In order to allow the original vegetation to regenerate, the regular clearing of bush growing up under the coconut palms was stopped. In addition the coconut crop continued to be harvested so as to prevent regeneration of coconut palms which, if allowed to

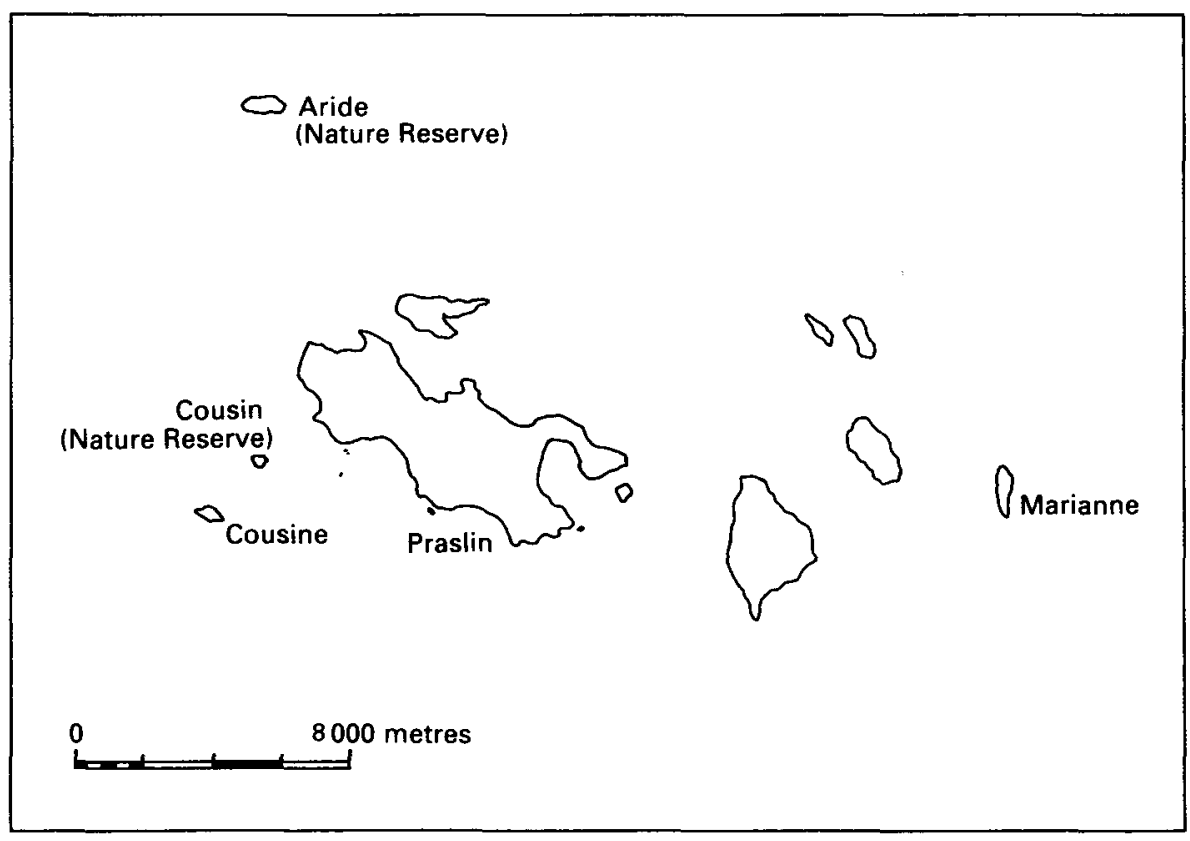

Figure 1. Map showing the Seychelles islands under discussion. 
grow unchecked, result in an impenetrable thicket of young palms, probably crowding out everything else. As a consequence the indigenous vegetation has quickly regenerated and is now tending towards predominantly Pisonia grandis forest. This has led to a spectacular recovery of the warbler, numbers rising to nearly 320 birds in 1982 (Figure 2). This recovery is partially documented in Collar and Stuart (1985) who record a somewhat slower recovery than shown in Figure 2. The data in Figure 2 are based on a re-examination of the original territory maps of Bathe and Bathe (1982) and N. J. Phillips (verbally) as well as more recent total counts. Since 1982 the population has fluctuated around that level, suggesting that this is the maximum carrying capacity of the island. The increase in number of territories showed the same trend, but reached its saturation level of $c .115$ territories earlier, in 1973.

\section{Justification for a Seychelles Warbler translocation}

The Seychelles Warbler has a clutch-size of one which, when combined with low breeding success, leads to a low reproductive rate (on average only 0.3 young per pair per year become adults). This need not be a severe problem if the pressures placed on reproduction are only temporary, since warblers are longlived (mean adult life expectancy is 3.9 years) and can therefore tolerate periods of low recruitment. They are particularly vulnerable to factors which lead to increased adult mortality and/or prolonged reduction in recruitment.

The Seychelles Warbler population on Cousin having reached carrying capacity, young birds were unable to establish new territories. Thus in order to give the species the security of two breeding populations, lest some ecological disaster should befall the parent population, King (1978-79) and Collar and Stuart (1985) recommended the establishment of a second population on another island.

We investigated several islands for their suitability for a transfer. While suitable habitat, including adequate insect food supplies, was clearly a priority, the

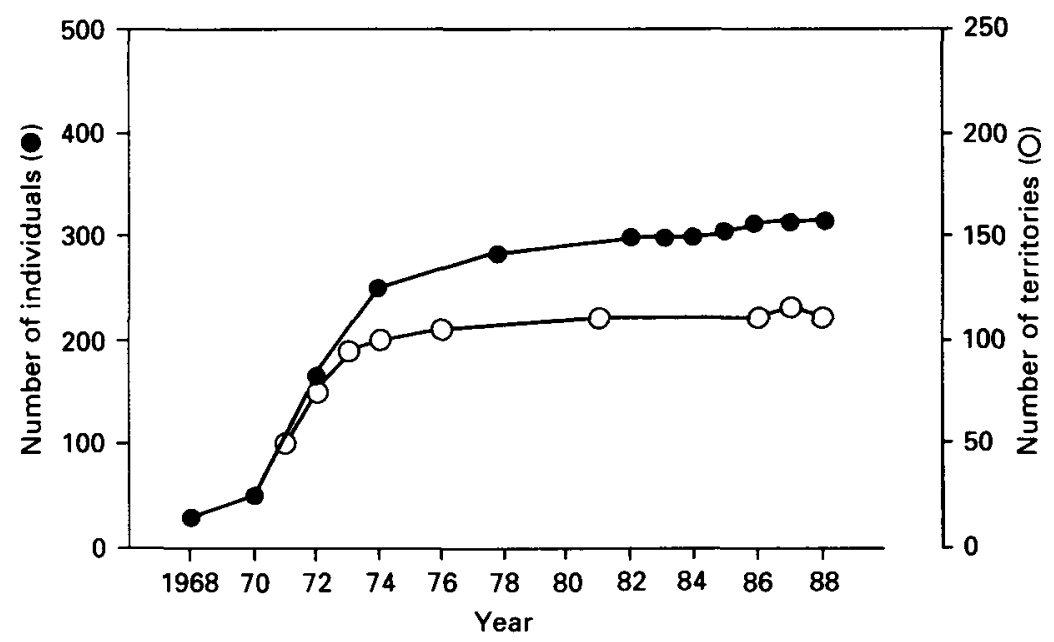

Figure 2. Increase in Seychelles Warbler numbers and territories since 1968. 
absence of cats and rats was also considered a precondition and some form of sustained commitment to conservation management seemed highly desirable. Of the possible islands fulfilling these criteria (Aride, Cousine and Frégate) Aride, nine kilometres north of Cousin, was selected (Figure 1). It is a nature reserve run and owned by the Royal Society for Nature Conservation (RSNC). The native woodland on Aride has recovered as swiftly as that on Cousin, and it was predicted that the warbler would fill an open niche (based on similarities in feeding ecology) without competing with the other four landbird species present (Komdeur unpublished data). Therefore a joint research programme on both islands was carried out to assess Aride's suitability for Seychelles Warblers (Komdeur in press a).

\section{Suitability of Aride Island for the Seychelles Warbler}

The foraging behaviour of Seychelles Warblers provided an excellent opportunity to assess the island's quality. As the warblers are insectivorous, taking $98 \%$ of their insect food from leaves, the quality of an island depends on insect prey available and amount of foliage. Island quality (iq) was therefore expressed in terms of mean number of prey insects available using the following equation (Komdeur in press b):

$$
\mathrm{iq}=\sum_{x=1}^{12} \mathrm{c}_{\mathrm{x}} \mathrm{i}_{\mathrm{x}}
$$

where: $c_{x}=$ mean yearly foliage cover for plant species $x$

$i_{x}=$ mean monthly insect totals for plant species $x$

Island quality of Cousin and Aride was studied between May 1987 and September 1988; insects and vegetation were monitored simultaneously on Cousin and Aride at 67 and 28 randomly chosen sites, respectively.

To monitor the effect of drought and wind direction on the vegetation, amount of foliage at each site was measured using a transect method, during both the dry (May-September) and wet (November-March) seasons. Each transect was $250 \mathrm{~m}$ long. Every five metres the presence or absence of foliage and the plant species was noted in the following height bands: $0-0.75 \mathrm{~m}, 0.75-2 \mathrm{~m}$, 2-4 $\mathrm{m}$, etc. Mean foliage cover for plant species $x\left(c_{x}\right)$ is two times the total number of cases of presence at all heights along a transect, divided by the number of transects.

To assess prey availability $\left(i_{x}\right)$ at each site, 50 leaves per plant species ( 12 dominant species) were searched for insects monthly (between $15^{\text {th }}$ and 2oth). Totals of the following groups were counted on upper and lower sites separately: Arachnida, Coleoptera, Diptera, Formicidae, other Hymenoptera, Hemiptera, Lepidoptera and Orthopthera.

The quality of Aride was on average 4.4 times higher than that of Cousin and the minimum quality was almost as high as the maximum recorded for Cousin (Figure 3). Because of the open niche present and this significantly higher quality, Aride was judged to be suitable for the establishment of a second warbler population. 


\section{Transfer of Seychelles Warblers to Aride Island}

Once Aride had been established as a suitable site for the Seychelles Warbler, ICBP, RSNC and the Seychelles government formally approved the translocation. For the transfer a target of 30 birds, with equal numbers of both sexes, was considered to be a reasonable number to remove from the Cousin population.

Research indicated that September 1988 would be the best time for the transfer. At this time moulting is complete, breeding mostly finished and food supply is still high enough for birds to be in prime condition (Komdeur in press a).

In mid-September all territories were checked for breeding birds and birds undergoing rectrice moult, in order to select 30 individuals for the transfer. Over the period 23-29 September trapping took place between o5hoo and o8hoo each morning, in four localities. At each locality two mist-nets and a portable taperecorder with a continuous loop cassette of male song was used for attracting birds.

The birds were weighed immediately after catching. To prevent aggression between territorial birds, each bird was kept in a separate $15 \times 15 \times 20 \mathrm{~cm}$ cardboard transfer cage, well ventilated, but dark inside in order to keep the birds inactive, thus reducing stress and energy loss. A stick trellis, $1 \mathrm{~cm}$ off the floor of each box, was also provided to allow the birds to perch inside. Birds were then taken to the laboratory, ringed, weighed again and sexed by measuring weight and wing length (see Diamond 1980).

During the period 29 adult warblers (16 males and 13 females) were rapidly transferred to Aride by motor-boat. The cardboard cages were kept secure in a

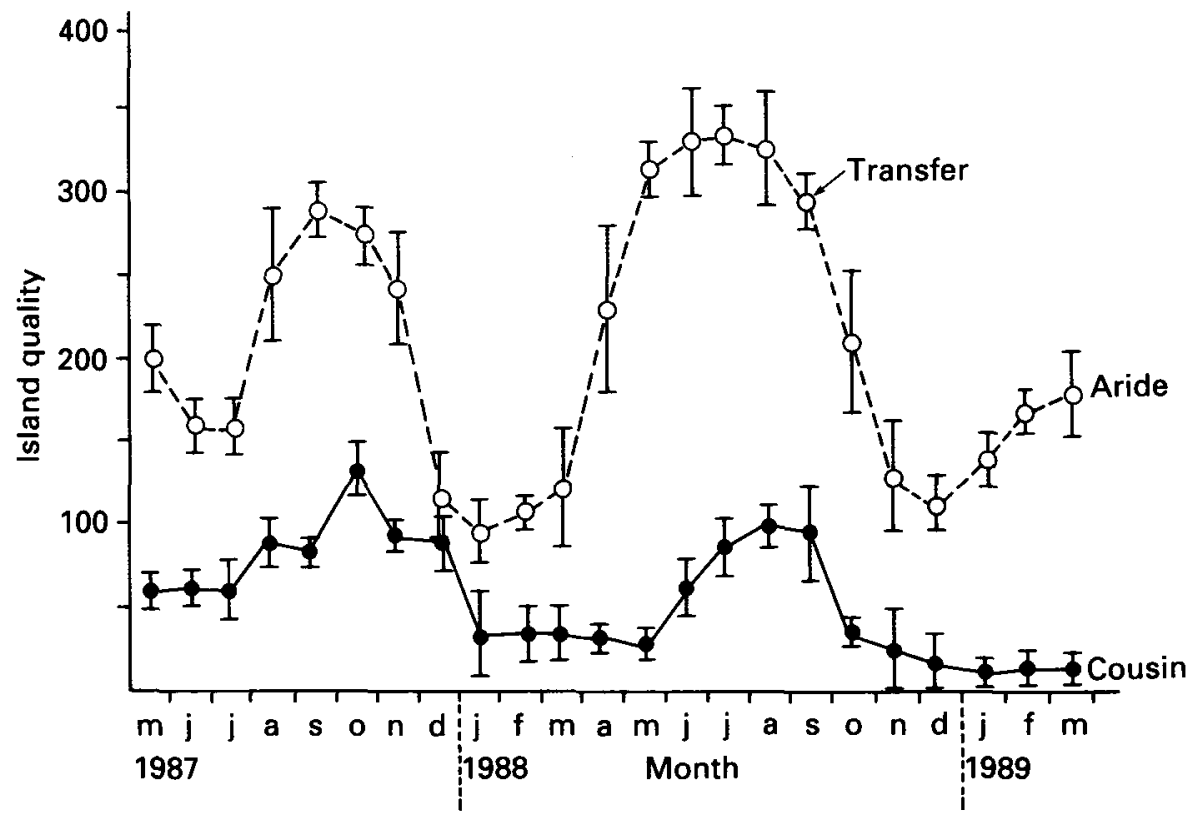

Figure 3. Monthly island quality (+ SE) of Aride Island (mean: 242) and of Cousin Island (mean: 55) (May 1987-March 1989). 
wooden carrying cage and placed on a thick foam mattress to absorb shocks in a rough sea.

Immediately on landing, the birds were taken to their release sites, the most insect- and vegetation-rich areas on Aride. The inter-island transfer of New Zealand Black Robins Petroica traversi (Flack 1977) showed that the transferred birds will settle as close to the release point as possible when the habitat is suitable; otherwise they move about or fail to form pairs. Before release birds were weighed again and water was provided by throwing buckets of water over the vegetation within a few metres of the cages.

\section{Evaluation of the transfer method}

The effect of the transportation method on the bird was assessed by weight changes of birds during captivity, the visual condition of birds at release and by survival and behaviour in subsequent weeks.

The alimentary canal of small insectivorous birds is adapted to continuous digestion. If stomach and intestine are completely empty (e.g. after fasting following catching and transport) then immediately after the loss of the last intestine contents a haemorrhagic diathesis can develop. This can arise very quickly in small birds with a high metabolism level and leads rapidly to death. There is a minimum weight below which birds will die so it is clearly vital that the handling of birds and total time in captivity is kept at an absolute minimum to prevent their weight falling below this critical level.

On average the 29 birds spent just over three hours in captivity. The minimum known survival weight is $14.6 \mathrm{~g}$ for males and $12.6 \mathrm{~g}$ for females, calculated as the lowest weight of known birds on Cousin Island still alive (Komdeur unpublished data). All birds survived the transfer and were released before they reached the minimum weight (Figure 4). Males lost on average $0.9 \mathrm{~g}$, females 1.o $\mathrm{g}$ (respectively $5.7 \%$ and $7.1 \%$ of body weight).

\section{Breeding activity following the transfer}

The most striking aspect of the transfer was the dramatic burst of nesting activity by Aride birds immediately following release. Successful nesting occurred within a few weeks and in one territory within three days of release. Four weeks after the transfer the first young (twins) hatched.

To detect breeding activity, all territories were checked weekly for active nests. Comparing breeding activity on both islands six months after the transfer, Aride birds showed on average 5.3 times more breeding activity than Cousin birds (Figure 5). A minimum of $64 \%$ of pairs bred on Aride in October and a maximum of $100 \%$ of pairs were breeding from January to March 1989. Over the same period the percentage of breeding pairs on Cousin varied from $0 \%$ in October and November to $31 \%$ in March. On Cousin birds undergo a prebreeding moult; a significant relation exists between the percentage of territories with nests and the percentage of moulting birds two months before (Komdeur in press b). On Aride moulting birds were still able to sustain active breeding at the same time. Given that island quality was 4.4 times as high and that territories were 4.8 times larger, on Aride the transferred birds have access to 21.1 times 


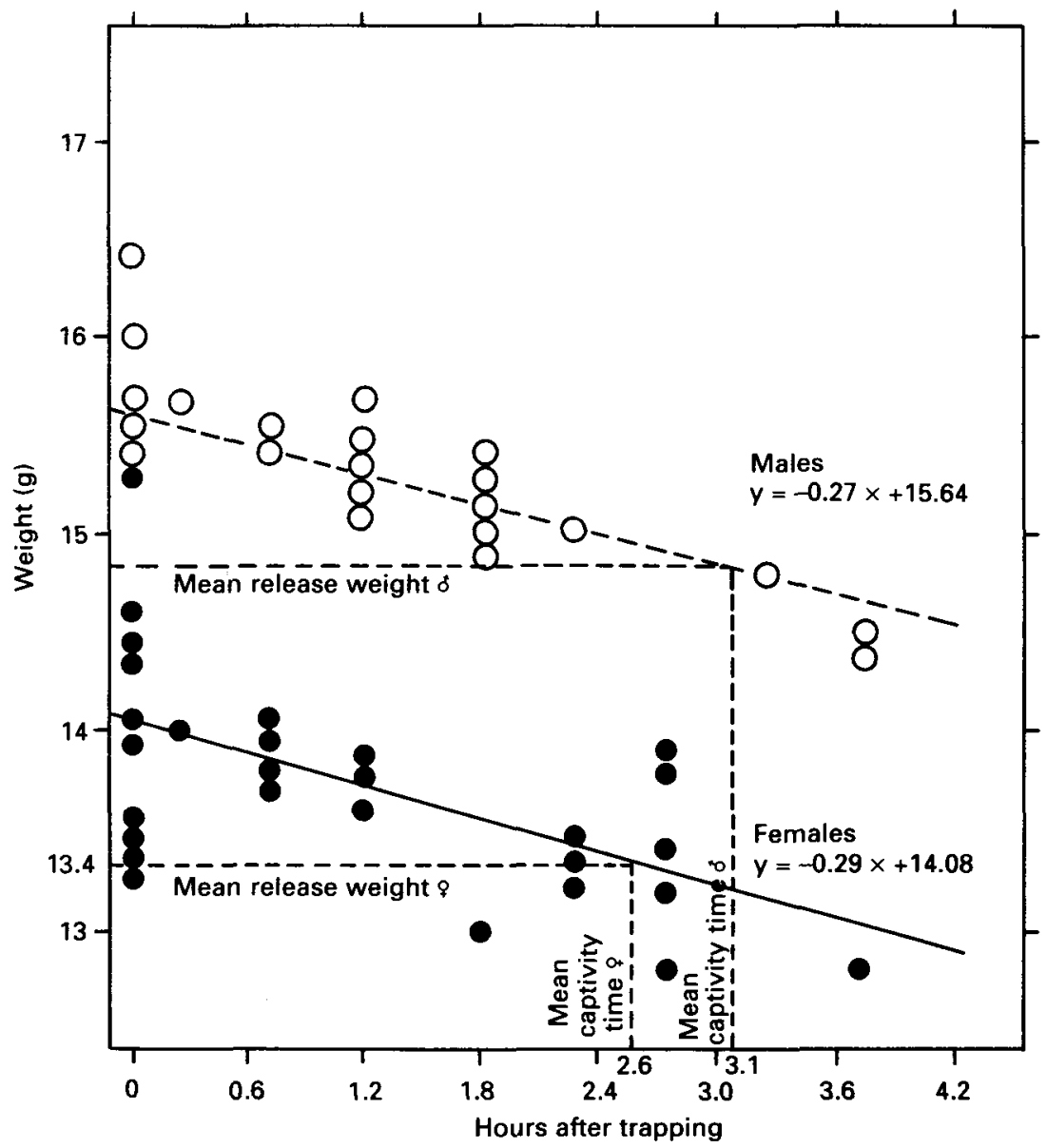

Figure 4. Weight loss of Seychelles Warblers (males: $\mathrm{r}=-0.83, \mathrm{df}=21, \mathrm{p}<0.001$; females: $\mathrm{r}=-0.61, \mathrm{df}=27, \mathrm{p}<0.001$ ) in captivity during transfer to Aride Island (September 1988). (Mean release weight and mean captivity time are given for both sexes.)

more food than birds on Cousin and so were able to sustain high continuous breeding activity.

Greater reproduction output on Aride was sustained for the six months following the transfer (Table 1). Among the most notable differences between islands were that on Aride mean clutch-size per pair was almost twice as high, young fledged five days earlier, mean number of nesting attempts per pair was 9.3 times as high and mean number of young reaching one year of age per pair was 16.3 times higher. The spaces vacated in territories on Cousin from which birds had been removed were filled by non-territorial birds within six hours (see Komdeur in press a).

A half-year after the transfer all transferred birds were still alive and 26 young had fledged successfully, bringing the total Aride population to 45 birds. With enough space still remaining on Aride for young birds to establish territories, the population is still growing. 


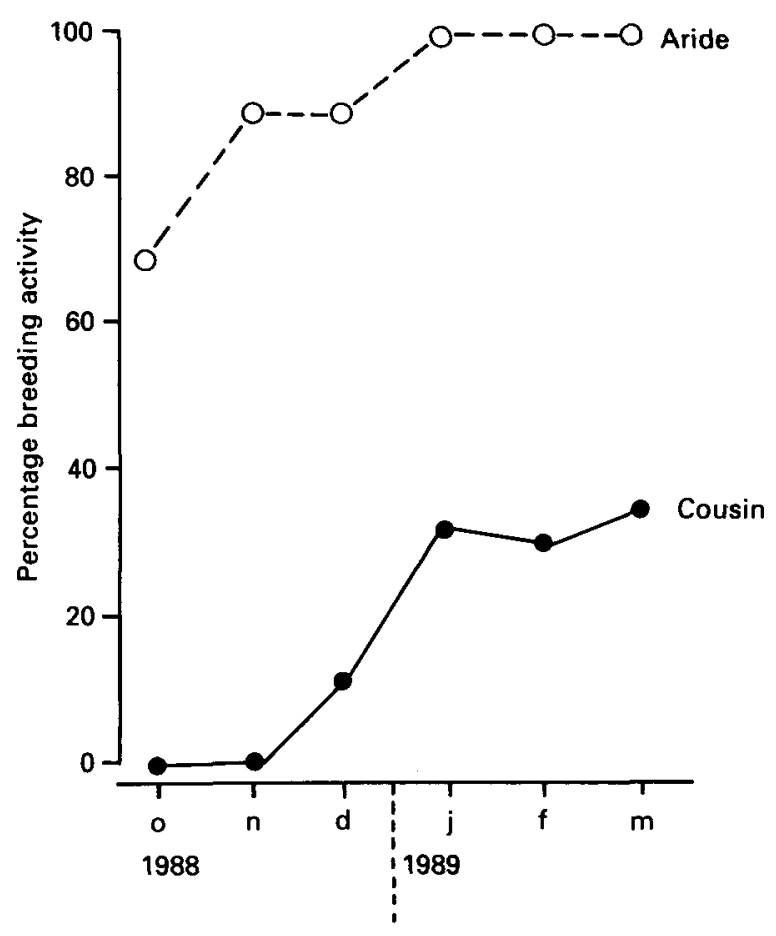

Figure 5. Percentage territories with breeding activity each month on Aride Island (mean: $91.7 \%, \mathrm{n}=15$ ) and on Cousin Island (mean: $17.3 \%, \mathrm{n}=117$ ).

Since the establishment of a healthy breeding population on Aride Island, we believe that the Seychelles Warbler is well on the way to being listed as "out of danger" in the next edition of Threatened birds of Africa and related islands.

\section{Acknowledgements}

The transfer was carried out for the International Council for Bird Preservation, which was ultimately responsible for its successful completion. We thank Christopher Cadbury who generously provided support and agreed to have warblers on Aride, and Victorin Laboudallon for his invaluable help during the transfer. We are most grateful to the

Table 1. Comparison of breeding performance of Seychelles Warblers on Cousin Island and Aride Island (figures in parentheses are number of observations)

\begin{tabular}{lccc}
\hline & Cousin & Aride & $t$ value \\
\hline Mean clutch-size & $1 \cdot 0(81)$ & $1 \cdot 8(33)$ & $15 \cdot 31^{*}$ \\
Mean no. days to fledge & $19 \cdot 1(63)$ & $14 \cdot 1(14)$ & $40 \cdot 44^{*}$ \\
Mean yearly young fledged/territory & $0 \cdot 6(210)$ & $5 \cdot 6(36)$ & $8 \cdot 45^{*}$ \\
Mean yearly young reaching & $0 \cdot 19(210)$ & $3 \cdot 10(36)$ & $9 \cdot 51^{*}$ \\
$\quad$ one year of age/territory & & & \\
\hline
\end{tabular}

${ }^{*} \mathrm{p}<0.001$ 
Seychelles government for its full cooperation, especially W. André, P. Lablache and J. Mascarenhas for giving their approval to the proposed translocation. Many thanks to A. Skerrett for being a middleman during this event and to J. Cadbury (RSPB) for his support throughout. For advice we are grateful to N. B. Davies (Cambridge University) and D. Merton (Department of Conservation, New Zealand). Many others have helped with the project and of these we would especially mention C. Braat, A. Datema, M. Glastra, S. Jakobsen, H. Kisbye, A. Ovaa, and B. Ferrari, L. Jeanvole for provision of excellent launch transport, and staff on Cousin and Aride. Finally we would like to thank Mariette Komdeur and Gill Lewis, who have helped in every imaginable way with field observations and in processing and analysing data, and N. J. Collar and N. B. Davies who made very useful suggestions for improving the paper.

\section{References}

Bathe, G. M. and Bathe, H. V. (1982) Territory size and habitat requirement of the Seychelles Brush Warbler Acroephalus (Bebrornis) sechellensis. International Council for Bird Preservation, Cousin Island Research Station, Techn. Rep. 18.

Collar, N. J. and Stuart, S. N. (1985) Threatened birds of Africa and related islands: the ICBP/ IUCN Red Data Book, Part 1. Cambridge, U.K.: International Council for Bird Preservation.

Crook, J. H. (1960) The present status of certain rare landbirds of the Seychelles Islands. Unnumbered Seychelles Government Bulletin.

Diamond, A. W. (1980) Seasonality, population structure and breeding ecology of the Seychelles Brush Warbler Acrocephalus sechellensis. Proc.4th Pan-African Orn. Congress.: 253-266.

Flack, J. A. D. (1977) Interisland transfers of New Zealand Black Robins. Pp. 365-372 in S. A. Temple ed. Endangered birds: management techniques for preserving threatened species. Madison: University of Wisconsin Press, and London: Croom Helm.

King, W.B. (1978-1979) Red data book, 2. Aves. Second edition. Morges, Switzerland: International Union for Conservation of Nature and Natural Resources.

Komdeur, J. (in press a) The conservation of the Seychelles Warbler Acrocephalus sechellensis. International Council for Bird Preservation (Technical Publication).

Komdeur, J. (in press b) Influence of territory quality and habitat saturation on dispersal options in the Seychelles Warbler Acrocephalus sechellensis; an experimental test of the habitat saturation for cooperative breeding. Proceedings of the 2oth International Ornithological Conference.

Oustalet, M. E. (1878) Etude sur la faune ornithologique des isles Seychelles. Bull. Soc. Philomath. Paris 7(2): 161-206.

\section{JAN KOMDEUR}

Department of Zoology, University of Cambridge, Cambridge CB2 oPJ, U.K.

IAN D. BULLOCK

6 Stampers Row, Parkend, Lydney, Gloucester GL15 4JL, U.K.

MICHAEL R. W. RANDS

International Council for Bird Preservation, 32 Cambridge Road, Girton, Cambridge $\mathrm{CB}_{3}$ oPJ, U.K. 